Yen, C., Tu, C., Sujo-Montes, L., \& Sealander, K. (2016). A Predictor for PLE Management: Impacts of Self-Regulated Online Learning on Students' Learning Skills. Journal of Educational Technology

\title{
A Predictor for PLE Management: Impacts of Self- Regulated Online Learning on Students' Learning Skills
}

\author{
Cherng-Jyh Yen \\ Old Dominion University \\ Chih-Hsiung Tu \\ Northern Arizona University \\ Laura Sujo-Montes \\ Northern Arizona University \\ Karen Sealander \\ Northern Arizona University
}

\begin{abstract}
Web 2.0 integration requires a high level of learner-centered skills to create a personal learning environment (PLE). The pedagogical capability of Web 2.0 could support and promote self-regulated learning (SRL) by enabling the constructions of PLEs. This study investigated how will each of the six aspects of self-regulated online learning (i.e., environment structuring, goal setting, time management, task strategies, help seeking, \& self-evaluation) respectively predict the level of initiative, the sense of control, and the level of self-reflection in personal learning environment (PLE) management. The study concluded that all six aspects of SRL could predict three types of PLE management besides environmental structuring to the level of initiative. Educators need to prepare all learners to advance their SRL to achieve sufficient PLE skills and knowledge to become competent digital network learners.
\end{abstract}

Keywords: Personal Learning Environment; Self-Regulated Learning; Learning Initiative; Sense of Control; Self Reflection; Network Learning Literacy

\section{Introduction}

Web 2.0 has become synonymous with a more interactive, open, networked, and collaborative Internet for learning. Mott (2010) argued that many educators considered the Learning Management System (LMS) as being too inflexible because it was a closed system. Educators are turning to Web 2.0 for tools to support communication, productivity, and 
collaboration needs. Therefore, educators have replaced the LMS with Web 2.0 tools, blogs, wikis, social networking sites, Google Apps, and other Web-based applications to enhance teaching and learning. Siemens and Matheos (2010) suggested that learners currently have more freedom to access, create, and recreate their learning contents, opportunities, and environments upon which to interact outside the institutional learning system. Educators who focus on the "social," "open," and "network" aspects have integrated multiple Web 2.0 technologies as the best strategy for learning (Dede, 2008) and supporting existing online instruction. The integration of multiple Web 2.0 tools (i.e., multi-tools platform) has been recognized as an instructional tool with autonomy, diversity, openness, and connectedness (vanHarmelen, 2006).

Web 2.0 integration requires a high level of learner-centered skills to create a PLE (Haworth, 2016; Suess \& Morooney, 2009; Weller, 2007). Learners are required to apply a personal customized portal to organize multiple technology tools in one central location such as personal or mobile portals. In other words, levels of initiative (Woolfolk et al., 2000), sense of control (Hall, 2009), and self-reflection (Zimmerman, 1998) are critical to build effective PLEs.

This study investigated the following research questions:

1. How will each of the six aspects of self-regulated online learning (i.e., environment structuring, goal setting, time management, task strategies, help seeking, $\&$ self-evaluation) respectively predict the level of initiative in personal learning environment (PLE) management?

2. How will each of the six aspects of self-regulated online learning (i.e., environment structuring, goal setting, time management, task strategies, help seeking, $\&$ self-evaluation) respectively predict the sense of control in personal learning environment (PLE) management?

3. How will each of the six aspects of self-regulated online learning (i.e., environment structuring, goal setting, time management, task strategies, help seeking, $\&$ self-evaluation) respectively predict the level of self-reflection in personal learning environment (PLE) management?

\section{Literature Review}

\subsection{Pesonal Learning Environment (PLE)}

New technologies enable individuals to personalize their learning environments through the integration of learning networks, people, resources, and tools, referred to as Personal Learning Environments (PLEs). van Harmelen (2008) argued PLE as an important factor in learner empowerment and self-directed learning facilitation. PLEs allow learners to control and manage their learning processes. Learners will also support setting their own learning goals, manage their learning contents and processes, and can communicate with others as part of the learning process so that their learning goals can be achieved (vanHarmelen, 2006). PLEs are a concept related to the use of technology for focused learning via the appropriation of tools and resources by the learners (Buchem et al., 2011). A PLE is composed of multiple subsystems, tools, and technologies. As suggested by Siemens (2007), PLE is a collection of tools integrated under the conceptual notion of openness, interoperability, and learner control. Therefore, learners are required to utilize a personalized portal in which multiple tools are organized into one central location to create a system 
of open network learning such as Symbaloo, Netvibes, Google Chrome apps, and mobile app platforms. In addition to the personal portal-based or personal dashboard-based PLE, there are other types of PLEs such as the blog-based PLE, E-mail-based PLE, and RSSbased PLE.

PLE is constructed with three networks (i.e., tool, people, and resources) and those three networks are connected to leaners via personal portal tools. Furthermore, PLE learners' envisions of how Web 2.0 tools (e.g., blogs, wikis, \& personal web portals), services (e.g., Diigo, Flickr, \& YouTube), people arrangement, and data sharing (e.g., social networking \& RSS) can be integrated and applied to learning processes (Casquero et al., 2010). Learners integrate personal portal technology access, manage, organize, and collaborate different Web 2.0 tools to form a personal tool network that supports learners to build different people networks such as professional, friends, family, local community, and global networks to reach effective learning resource network.

Personalization and appropriation of technologies based on learning goals are essential to the development of a PLE. Personalization and a sense of control are key factors in the successful use of Web 2.0 technologies. Importantly, if students do not perceive the technology or platform provided by their institutions as useful and practical, they are motivated to favor their own personalized approach and preferred tools (Conole, 2008). Furthermore, if students are not clear of their learning goals and how to appropriate relevant technologies to achieve these goals, an effective PLE will not occur. del Barrio-García et al. (2015) found modeling a high explanatory power of the intention in using PLE would support the role of Need for Cognition (NFC).
PLE is more than just technology or applying technologies to build virtual people and resource networks. Educators should focus on the utility of PLE in connecting people, tools, and resources networks. Therefore, PLE is both a technological and pedagogical concept. As suggested by Buchem (2012), the PLE concept focuses on the management and appropriation of different tools and resources by individual learners situated within a complicated social context. The social context will influence learners' ways of using media, participate in activities, and engage in collaborative communities (Bidarra \& Araújo, 2013). It is critical to note that simply integrating PLE to enhance any digital learning without effective modeling, understanding, and training would not result in positive learning outcomes. This is also dependent upon students' academic success (Kožuh, 2015), student interaction (Saz et al., 2016), and social capital (Casquero et al., 2016);

Three characteristics of PLE have been identified as ownership, control, and literacy (Bidarra \& Araújo, 2013). From management and practical aspects, they can be translated into the level of initiative, sense of control, and level of self-reflection. Level of initiative in PLE affects management (i.e., search, evaluate, select, add, delete, or move) of PLE widgets and tools to construct effective PLEs. On the other hand, a sense of control is demonstrated by taking control of the learning environment via managing different learning widgets and tools. Level of initiative is evidently related to initial preparations for network learning while sense of control is derived from the subsequent learning acts. Therefore, it is not feasible to assume that self-regulated learning will result in stronger self-related learning skills and effective PLE construction. Instead, learners may initially construct their PLEs, but not feel a strong 
sense of control in the subsequent management of their PLEs.

\subsection{Self-Regulated Learning (SRL)}

Self-regulated learning skills include goal setting, time management, task strategies, and environment structuring (Barnard-Brak et al., 2010). Goal setting involves selecting personal learning standards for short and long term learning goals. Time management consists of allocating, scheduling, and distributing time for learning. Task strategies include behaviors to curtail the distractions to learning such as taking notes, reading aloud, preparing questions, and pursuing extra work. Environmental structuring looks at how the physical environments may be rearranged to avoid distractions and enhance learning.

Self-regulated learning in digital learning is grounded in the active and resourceful behaviors on the part of individuals to achieve their learning (Woolfolk, Winne, \& Perry, 2000), "Self-regulated learning is seen as a mechanism to help explain achievement differences among students and as a means of improving achievement" (Schunk, 2005, p. 85). This is closely related to academic outcome in online learning, blended learning, and face-to-face learning. Barnard-Brak et al. (2010) noted that learners with higher selfregulated learning skills have more positive academic learning outcomes relative to their counterparts with no demonstration of selfregulated learning behaviors. In a blended environment, Lin et al. (2016) found selfregulated learning with group awareness and peer assistance provides significantly more active participation, better self-regulated behavior, and better learning achievement. Lee (2016) concluded that teacher scaffolding through modeling and timely feedback affected student self-regulated efforts in online learning.In fact, self-regulated strategies in flipped learning can improve learners' selfefficacy and their strategies of planning and using study time (Lai \& Hwang, 2016). They concluded students learn effectively and have better learning achievements.

\subsection{PLE and Self-regulated Learning}

Kitsantas and Dabbagh (2010) noted that the pedagogical capability of Web 2.0 could support and promote self-regulated learning by enabling the construction of PLEs. They contended that self-regulated learning and PLE building were interdependent and synergistic. PLE was also considered as critical skills to develop personal knowledge management strategies and the formation of a self-regulated learning model (Vázquez-Cano et al.,2016). Delenand Liew (2016) argued that selfregulation was one of the predictors of student performance in both traditional and digital personal learning environments.Self-regulated learning is based on the assumption that learners act as causal agents in their learning and lives (Martin, 2004, p. 135). Their choices may include setting personal goals, managing time, tasks, networks, and environments, and progressing to socially mediated knowledge and networked learning (Dabbagh \& Reo, 2011; Turker \& Zingel, 2008).

To examine PLEs from the social cognitive perspective, the development of self-regulated learning skills and strategies is a function of the bidirectional interaction of personal, behavioral, and environmental factors, which take the form of triadic reciprocal causation (Bandura, 1986; Schunk, 2001; Zimmerman, 1994). The development and the process of self-regulated learning skills and strategies depend on personal, behavioral, and environmental factors that enable learners to adjust, modify, organize, and manage their learning acts. Therefore, learners are required to apply a personal, customized portal to 
organize multiple digital tools in one central location.In the construction of a Web 2.0 PLE, the development of a personal factor allows learners to customize and personalize PLEs by managing digital widgets, mobile apps, and feeds into personal Web portals. Learners must develop a custom to regularly monitor personal portals to support their formal, nonformal, informal, lifelong (Haworth, 2016), and personal learning goals on different equipment and devices. The effective development of PLEs require learners to take charge of their PLE constructions, organizations, and managements. Because PLE building requires learnersto initiate and control, PLEs engage learners in a more focused manner by allowing them to design their own learning environments and by emphasizing the self-regulated nature of the learning (Valtonen et al., 2012).

\section{Method}

\subsection{Participants}

One hundred and four Educational Technology graduate students taking online courses participated by responding voluntarily to an online survey at a four-year public southwestern university in the United States. The participants were engaged in the online courses designed by integrating open network learning environments through utilizing multiple Web 2.0 tools (see Appendix A). The demographic information of the participantsis listed in Table 1. Overall, the majority of the participants were female $(\mathrm{n}=61,58.65 \%)$, Caucasian American $(\mathrm{n}=81,77.88 \%)$, and aged from 26 to 35 years old ( $\mathrm{n}=55,52.88 \%$ ).

\subsection{Measurement of Research Variables}

The online survey was revised from the Online Self-Regulated Learning Questionnaire (OLSQ) (Barnard-Brak et al., 2010) to refelct the emerging, complicated, and multiple learning platforms.

Criterion variables. The criterion variables were a participant's (a) level of initiative, (b) sense of control, and (c) level of selfreflectionin personal learning environment (PLE) management measured by the total scores from various numbers of items on a 5-point Likert scale (see Table 2).

Predictor variables. The predictor variables represented different aspects of self-regulated online learning: (a) environment structuring, (b) goal setting, (c) time management, (d) task strategies, (e) help seeking, and (f) selfevaluation. They were measured by the total scores from various numbers of items on a 5-point Likert scale (see Table 3).

\section{Data Analysis}

All data analyses were conducted with the IBM SPSS Statistics 21. Furthermore, the alpha level was set at .05 for all significance tests.

Linear regression analyses. Linear regression analyses (Cohen, Cohen, West, \& Aiken, 2003; Norusis, 2012) were conducted to assess the predictive relationship between one of the predictor variables and each of the criterion variables respectively. In total, eighteen simple regression models were fitted to the data to address the research questions of interest.

Significance test. The one-tailed t test of the regression coefficient of a predictor was used to assess the linear predictive relationship between that particular predictor and a criterion variable (Cohen et al., 2003; Norusis, 2012). The null hypothesis in the one-tailed $t$ tests was set as H0: $=0$. On the other hand, the 
Table 1. Demographic Information of Participants $(\mathrm{N}=104)$

Variable

Gender

Female

Frequency

Percent

\begin{tabular}{|c|c|c|c|}
\hline \multicolumn{4}{|l|}{ Gender } \\
\hline & Male & 43 & 41.35 \\
\hline & Female & 61 & 58.65 \\
\hline \multicolumn{4}{|c|}{ Ethnicity } \\
\hline & Caucasian & 81 & 77.88 \\
\hline & Latino & 17 & 16.35 \\
\hline & $\begin{array}{l}\text { Asian\& Pacific } \\
\text { Islander }\end{array}$ & 6 & 5.77 \\
\hline \multicolumn{4}{|l|}{ Age } \\
\hline & $18-25$ & 1 & .96 \\
\hline & $26-35$ & 55 & 52.88 \\
\hline & $36-45$ & 25 & 24.24 \\
\hline & $>45$ & 23 & 22.12 \\
\hline
\end{tabular}

alternative hypothesis was set as $\mathrm{H} 1:>0$ due to the expectation of the positive predictive relationships between research variables.

Effect sixe index.In each simple regression model, the squared multiple correlation coefficient $\left(\mathrm{R}^{2}\right)$ (Cohen et al., 2003; Norusis, 2012) was computed to estimate the proportion of variance in a criterion variable associated with, then predictable by a predictor variable. Moreover, the adjusted squared multiple correlation coefficients (adjusted $\mathrm{R}^{2}$ ) were obtained to correct the positive bias of the sample squared multiple correlation coefficients and serve as a more accurate estimator of their population counterparts (Cohen et al.). A negative adjusted squared multiple correlation coefficient is mathematically possible and is reported as 0 (Cohen et al.)

\section{Results}

5.1. Descriptive Statistics of the Research Variables 
Table 2. Online Survey Items Measuring Different Criterion Variables

\begin{tabular}{|c|c|}
\hline Variable & Survey Item \\
\hline \multirow{7}{*}{$\begin{array}{l}\text { Level of } \\
\text { initiative }\end{array}$} & I actively manage (Add; Delete; Move) my PLE (Symbaloo tiles, mobile apps etc.). \\
\hline & $\begin{array}{l}\text { I actively manage (Set; Update) my personal learning goals with PLE (Symbaloo tiles, } \\
\text { mobile apps etc.). }\end{array}$ \\
\hline & I actively share my PLE (Symbaloo tiles, mobile apps etc.) with other users. \\
\hline & I actively manage (Add; Delete; Move) my PLE (Symbaloo, mobile devices etc.) tabs. \\
\hline & I actively search for newer and more effective PLE (Symbaloo tiles, mobile apps etc.). \\
\hline & I actively access my PLE (Symbaloo tiles, mobile apps etc.). \\
\hline & I actively utilize my PLE (Symbaloo, mobile devices etc.) to support my own learning. \\
\hline \multirow[t]{9}{*}{$\begin{array}{l}\text { Sense of } \\
\text { control }\end{array}$} & $\begin{array}{l}\text { I actively connect to people, learning tools, and learning resources within PLE (Symbaloo, } \\
\text { mobile devices etc.). }\end{array}$ \\
\hline & $\begin{array}{l}\text { With PLE (Symbaloo, mobile devices etc.), I feel that I take control of my own learning } \\
\text { environment by managing different learning tools. }\end{array}$ \\
\hline & $\begin{array}{l}\text { Within PLE (Symbaloo, mobile devices etc.), when faced with a problem I try to solve it } \\
\text { myself. }\end{array}$ \\
\hline & $\begin{array}{l}\text { Within PLE (Symbaloo, mobile devices etc.), I can make decisions and be responsible for } \\
\text { my own learning. }\end{array}$ \\
\hline & $\begin{array}{l}\text { Within PLE (Symbaloo, mobile devices etc.), if I want to achieve something, I work hard to } \\
\text { get it. }\end{array}$ \\
\hline & $\begin{array}{l}\text { Within PLE (Symbaloo, mobile devices etc.), I consider different sides of an issue before } \\
\text { making any decisions. }\end{array}$ \\
\hline & $\begin{array}{l}\text { I do not get discouraged when doing something on PLE (Symbaloo, mobile devices etc.) } \\
\text { that takes a long time to achieve results. }\end{array}$ \\
\hline & $\begin{array}{l}\text { Within PLE (Symbaloo, mobile devices etc.), I can control my learning from anywhere at } \\
\text { anytime from any computing devices. }\end{array}$ \\
\hline & $\begin{array}{l}\text { With PLE (Symbaloo, mobile devices etc.), my performance control positively enhances } \\
\text { my attention, affect, and monitoring of my learning action. }\end{array}$ \\
\hline \multirow{7}{*}{$\begin{array}{l}\text { Level of } \\
\text { self- } \\
\text { reflection }\end{array}$} & $\begin{array}{l}\text { I would like to use PLE (Symbaloo, mobile devices etc.) to support my own teaching \& } \\
\text { learning in the future. }\end{array}$ \\
\hline & $\begin{array}{l}\text { Within PLE (Symbaloo, mobile devices etc.), whenever something good happens to me, I } \\
\text { feel it is because I've earned it. }\end{array}$ \\
\hline & Within PLE (Symbaloo, mobile devices etc.), I feel being in a position of leadership. \\
\hline & $\begin{array}{l}\text { With PLE (Symbaloo, mobile devices etc.), I feel that I am empowered to create my own } \\
\text { learning environment. }\end{array}$ \\
\hline & $\begin{array}{l}\text { With PLE (Symbaloo, mobile devices etc.), I feel that I am empowered to create my own } \\
\text { learning program }\end{array}$ \\
\hline & $\begin{array}{l}\text { With PLE (Symbaloo, mobile devices etc.), I am positively motivated toward creating my } \\
\text { own learning environment. }\end{array}$ \\
\hline & $\begin{array}{l}\text { With PLE (Symbaloo, mobile devices etc.), I continuously reflect on my online learning } \\
\text { after this course. }\end{array}$ \\
\hline
\end{tabular}


Table 3. Online Survey Items Measuring Different Predictor Variables

\begin{tabular}{|c|c|}
\hline Variable & Survey Item \\
\hline \multirow[t]{9}{*}{ Goal setting } & I set standards for my assignment in online course. \\
\hline & $\begin{array}{l}\text { I set short-term (daily or weekly) goals as well as long term goals (monthly or for the } \\
\text { semester) }\end{array}$ \\
\hline & I keep a high standard for my learning in my online courses. \\
\hline & I set goals to help me manage studying time for my online courses. \\
\hline & I don't compromise the quality of my work because it is online. \\
\hline & I set goals for my formal learning. \\
\hline & I set goals for my informal learning (Lifelong learning, personal interests.) \\
\hline & I apply online technologies to support goals. \\
\hline & $\begin{array}{l}\text { I constantly search, evaluate, select, and reselect online technologies to reflect my } \\
\text { current goals. }\end{array}$ \\
\hline \multirow{5}{*}{$\begin{array}{l}\text { Environmental } \\
\text { structuring }\end{array}$} & I choose the location where I study to avoid too much distraction. \\
\hline & I find a comfortable place to study. \\
\hline & I know where I can study most efficiently for online courses. \\
\hline & I choose a time with few distractions for studying for my online courses. \\
\hline & I use mobile devices (smartphones, tablets etc.) to help me to study. \\
\hline \multirow[t]{9}{*}{ Task strategies } & $\begin{array}{l}\text { I try to take more thorough notes for my online courses because notes are even more } \\
\text { important for learning online than in a regular classroom. }\end{array}$ \\
\hline & I read aloud instructional materials posted online to fight against distractions. \\
\hline & I prepare my questions before joining in the chat room and discussions. \\
\hline & $\begin{array}{l}\text { I work extra problems in my online courses in addition to the assigned ones to master } \\
\text { the course content. }\end{array}$ \\
\hline & I build "people network" online to help me to learn. \\
\hline & I build "resources network" online to help me to learn. \\
\hline & I build and connect "tools/technologies network" online to help me to learn. \\
\hline & I use online technologies to collaborate with others to help me to learn. \\
\hline & I manage online tools and technologies regularly to help me to learn. \\
\hline
\end{tabular}




\begin{tabular}{|c|c|}
\hline Variable & Survey Item \\
\hline \multirow[t]{5}{*}{$\begin{array}{l}\text { Time } \\
\text { management }\end{array}$} & $\begin{array}{l}\text { I allocate extra studying time for my online courses because I know it is time- } \\
\text { demanding. }\end{array}$ \\
\hline & $\begin{array}{l}\text { I try to schedule the same time every day or every week to study for my online courses, } \\
\text { and I observe the schedule. }\end{array}$ \\
\hline & $\begin{array}{l}\text { Although we don't have to attend daily classes, I still try to distribute my studying time } \\
\text { evenly across days. }\end{array}$ \\
\hline & $\begin{array}{l}\text { I frequently allocate small chunks of time to engage in just-in-case, just-in-time, and } \\
\text { bite size learning. }\end{array}$ \\
\hline & I frequently allocate substantial chunks of time to engage in learning. \\
\hline \multirow[t]{6}{*}{ Help seeking } & $\begin{array}{l}\text { I find someone who is knowledge in course content so that I can consult with him or } \\
\text { her. }\end{array}$ \\
\hline & $\begin{array}{l}\text { I share my problems with my classmates online so we know what we are struggling } \\
\text { with and how to solve our problems. }\end{array}$ \\
\hline & If needed, I try to meet my classmates face-to-face. \\
\hline & I am persistent in getting help from the instructor through e-mail. \\
\hline & I am persistent in getting help by using different devices (computers, mobile devices). \\
\hline & $\begin{array}{l}\text { I am persistent in getting help by using different technologies (Twitter, social networks } \\
\text { etc.). }\end{array}$ \\
\hline \multirow[t]{6}{*}{$\begin{array}{l}\text { Self- } \\
\text { evaluation }\end{array}$} & $\begin{array}{l}\text { I summarize my learning in online courses to examine my understanding of what I have } \\
\text { learned. }\end{array}$ \\
\hline & $\begin{array}{l}\text { I ask myself a lot of questions about the course materials when studying for an online } \\
\text { course. }\end{array}$ \\
\hline & I communicate with my classmates to find how I am doing in my online classes. \\
\hline & $\begin{array}{l}\text { I communicate with classmates to find what I am learning that is different from what } \\
\text { they are learning. }\end{array}$ \\
\hline & $\begin{array}{l}\text { I use different technologies to reflect my online learning, such as online portfolio, } \\
\text { personal blogs, Twitter, social media etc. }\end{array}$ \\
\hline & $\begin{array}{l}\text { I re-evaluate online tools and technologies that I used for my online learning after each } \\
\text { online course I took. }\end{array}$ \\
\hline
\end{tabular}

The descriptive statistics of the criterion variables are listed in Table 4. Overall, participants had higher level of self-reflection and sense of control in PLE management with the average result per item greater than 3 , but a lower level of initiative in PLE management with the average result per item lower than 3 .

The descriptive statistics of the predictor variables are listed in Table 5.As a group, participants seemed to have a stronger selfregulation in environment structuring and goal setting with average results per item greater than 4 , but weaker self-regulation in time management, task strategies, help seeking, and self-evaluation with the average results per item less than 4. 


\subsection{Level of Initiative as the Criterion Variable}

The regression analysis results (see Table 6) suggested that five of the six aspects of selfregulated online learning with environmental structuring as the exception were predictors of level of initiative in PLE management. In addition, the signs of the related regression coefficients supported the theoretically expected positive linear relationships between each statistically significant predictor and level of initiative in PLE management.

The values of the $\mathrm{R}^{2}$, ranged from .03 to .14 , and adjusted $\mathrm{R}^{2}$, ranged from .03 to .13 indicated moderate predictive relationships between five aspects of self-regulated online learning and level of initiative in PLE management.

\subsection{Sense of Control as the Criterion Variable}

According to the regression analyses results (see Table 7), each of the six aspects of self-regulated online learning could predict sense of control in PLE management. The above predictive relationships were positive as theoretically expected based on the actual signs of the related regression coefficients.

The values of the $\mathrm{R}^{2}$, ranged from .05 to .23 , and adjusted $\mathrm{R}^{2}$, ranged from .04 to .22 suggested moderate predictive relationships between the six aspects of self-regulated online learning and sense of control in PLE management.

\subsection{Level of Self-reflection as the Criterion Variable}

The results (see Table 8) supportedthe positive predictive relationships between each of the six aspects of self-regulated online learning and level of self-reflection in PLE management.

The values of the R2, ranged from .04 to .16 , and adjusted $\mathrm{R} 2$, ranged from .03 to .15

Table 4. Descriptive Statistics of the Criterion Variables $(\mathrm{N}=104)$

\begin{tabular}{|c|c|c|c|c|c|c|}
\hline Variable & $\begin{array}{l}\text { \# of survey } \\
\text { items }\end{array}$ & M & Mdn & $\mathrm{SD}$ & Minimum & Maximum \\
\hline $\begin{array}{l}\text { Level of } \\
\text { initiative }\end{array}$ & 7 & 17.25 & 17.00 & 7.72 & 7.00 & 34.00 \\
\hline $\begin{array}{l}\text { Sense of } \\
\text { control }\end{array}$ & 9 & 29.75 & 30.00 & 8.37 & 9.00 & 45.00 \\
\hline $\begin{array}{l}\text { Level of self- } \\
\text { reflection }\end{array}$ & 7 & 23.56 & 24.00 & 7.21 & 7.00 & 35.00 \\
\hline
\end{tabular}

Note.Survey items were constructed with a 5-point Likert scale ranged from 1 as strongly disagree to 5 as strongly agree. 
Table 5. Descriptive Statistics of the Predictor Variables $(\mathrm{N}=104)$

\begin{tabular}{lllllll}
\hline Variable & $\begin{array}{l}\text { \# of survey } \\
\text { items }\end{array}$ & M & Mdn & SD & Minimum & Maximum \\
\hline Environment structuring & 9 & 38.37 & 39.00 & 5.36 & 17.00 & 45.00 \\
Goal setting & 5 & 20.30 & 21.00 & 3.59 & 6.00 & 25.00 \\
Time management & 5 & 18.61 & 19.00 & 3.43 & 7.00 & 25.00 \\
Task strategies & 9 & 32.79 & 32.00 & 5.47 & 19.00 & 45.00 \\
Help seeking & 6 & 21.41 & 21.00 & 3.82 & 10.00 & 30.00 \\
Self-evaluation & 6 & 21.83 & 22.00 & 4.05 & 9.00 & 35.00 \\
\hline
\end{tabular}

Note.Survey items were constructed with a 5-point Likert scale ranged from 1 as strongly disagree to 5 as strongly agree.

indicated moderate predictive relationships between six aspects of self-regulated online learning and level of self-reflection in PLE management.

\section{Discussion}

This study has found that all six aspects of SRL could predict level of initiative, sense of control, and self-reflection in
PLE management besides environmental structuring to level of initiative.

\subsection{Level of initiative}

Five aspects of SRL skills and knowledge are critical to the level of initiative except for environmental structuring. Level of initiative in creating, and organizing PLE is related to managing (search, evaluate, select, add, delete,

Table 6. Descriptive Statistics of the Predictor Variables $(\mathrm{N}=104)$

\begin{tabular}{llllll}
\hline Variable & $\mathrm{B}$ & $\mathrm{t}$ & $\mathrm{df}$ & $\mathrm{R}^{2}$ & adj. $\mathrm{R}^{2}$ \\
\hline Environment structuring & .28 & 1.32 & 102 & .02 & .01 \\
Goal setting & .54 & $4.04^{*}$ & 102 & .14 & .13 \\
Time management & .52 & $2.37^{*}$ & 102 & .05 & .04 \\
Task strategies & .26 & $1.91^{*}$ & 102 & .03 & .03 \\
Help seeking & .50 & $2.58^{*}$ & 102 & .06 & .05 \\
Self-evaluation & .69 & $3.94^{*}$ & 102 & .13 & .12 \\
\hline
\end{tabular}

Note. $\mathrm{B}=$ unstandardized regression coefficient; $\mathrm{t}=$ tone-tailed test statistic; $\mathrm{df}=$ degrees of freedom; R2= squared multiple correlation coefficient; adj. R2= adjusted squared multiple correlation coefficient.

$* \mathrm{p}<.05$ 
share, or move) gadgets/tools/apps to meet the short-term and long-term learning goals on the part of the learner. This requires learners to engage in "externalization acts" to build their ideal environments on and with technologies.

Although all participants completed their PLE initially as the instructional requirement, the level of initiative was the lowest in all three PLE management (see Table 4). This finding appears that the participants have lacked knowledge and skills in initiating and managing their PLEs. Likely, learners do not fully understand the intentions and the concepts of building PLE for formal learning. Particularly, social context impacts how learners use media to support their personal learning (Buchem, 2012). Another explanation is from the aspect of perception. All learners have been equipped with relevant LMS

Table 7. Six Simple Regression Models with Sense of Control as the Criterion Variable

\begin{tabular}{llllll}
\hline Variable & $\mathrm{B}$ & $\mathrm{t}$ & $\mathrm{df}$ & $\mathrm{R}^{2}$ & adj. $\mathrm{R}^{2}$ \\
\hline Environment structuring & .74 & $5.44^{*}$ & 102 & .23 & .22 \\
Goal setting & .64 & $2.89^{*}$ & 102 & .08 & .07 \\
Time management & .75 & $3.28^{*}$ & 102 & .10 & .09 \\
Task strategies & .34 & $2.30^{*}$ & 102 & .05 & .04 \\
Help seeking & .70 & $3.38^{*}$ & 102 & .10 & .09 \\
Self-evaluation & .87 & $4.71^{*}$ & 102 & .18 & .17 \\
\hline
\end{tabular}

Note. $\mathrm{B}=$ unstandardized regression coefficient; $\mathrm{t}=$ tone-tailed test statistic; $\mathrm{df}=$ degrees of freedom; R2 = squared multiple correlation coefficient; adj. R2= adjusted squared multiple correlation coefficient.

$* \mathrm{p}<.05$

Table 8. Six Simple Regression Models with Level of Self-reflection as the Criterion Variable

\begin{tabular}{llllll}
\hline Variable & $\mathrm{B}$ & $\mathrm{t}$ & $\mathrm{df}$ & $\mathrm{R}^{2}$ & adj. $\mathrm{R}^{2}$ \\
\hline Environment structuring & .28 & 1.32 & 102 & .16 & .15 \\
Goal setting & .53 & $4.35^{*}$ & 102 & .07 & .06 \\
Time management & .61 & $3.06^{*}$ & 102 & .08 & .08 \\
Task strategies & .25 & $1.97^{*}$ & 102 & .04 & .03 \\
Help seeking & .56 & $3.12^{*}$ & 102 & .09 & .08 \\
Self-evaluation & .68 & $4.19^{*}$ & 102 & .15 & .14 \\
\hline
\end{tabular}

Note. $\mathrm{B}=$ unstandardized regression coefficient; $\mathrm{t}=$ tone-tailed test statistic; $\mathrm{df}=$ degrees of freedom; $\mathrm{R} 2=$ squared multiple correlation coefficient; adj. $\mathrm{R} 2=$ adjusted squared multiple correlation coefficient.

$* \mathrm{p}<.05$ 
skills, but saw PLE building as an additional workload to fulfil the requirement rather than supporting learning. Sixty-eight percent of learners have used PLE for the first time. Most learners do not go beyond the course requirements to create, search, access, update, share, and manage their PLE to reflect their own learning. More than $44 \%$ has accessed PLE less than weekly. Half of the participants rarely or never managed their PLE. Fifty-night percent do not add any additional gadgets, tools, or apps to their PLEs while $65.38 \%$ have created two tabs/screens as required. Similar results are found in Sahin and Uluyol's study (2016) that PLE construction and management have been limited.

Noteworthy is that the environmental structuring could not predict the level of initiative. Interestingly, this observation correlates with the level of initiative having the lowest score in all three PLE managements while environmental structuring has the highest score in all six SRL aspects. Learners are more inclined to physical learning environment structuring rather than digital and mobile environments. Effective PLE management engages learners in physical, digital, and mobile platforms. This could be explained by the fact that learners have high ownerships and access to mobile devices (smartphones, 68.38\%; tablets, 73.08\%). This validates the literature that learners may not perceive mobile PLE as formal learning platforms (Camacho and Guilana, 2011), but rather for just-in-time (Peters, 2007) communication, social, or entertainment purposes (Mostmans et al., 2012).

PLE is more than just a digital PLE. More precisely, effective PLE should be built to fuse physical, digital, and mobile PLEs to achieve learning anywhere, anytime, and ubiquitous learning (Taraghi, 2012). As a result, learning becomes more context- rich. Physical PLE, digital PLE, and mobile PLE should enhance, extend, and enrich one another. Digital and mobile PLEs do not occur in a vacuum. Frequently, it commences with physical PLE and affords individuals to explore digital worlds to extend their physical PLE. With digital and mobile technologies support, physical PLE could transcend the physical boundary and spatial and temporal constraints. With more advanced digital mobile technologies, mobile PLE becomes more critical to building PLE.

Commonly, learners may not truly understand that PLE is more than technical constructions. In addition, they may not grasp the prominence of Connectivist learning in PLE via nurturing human network, resource network, and tool/technology network. They see the convenience of PLE, but failed to perceive PLE as a living and constantly evolving environment. For many learners, PLE may mean desktop or laptop computer platforms. Mobile devices, such as smartphones, and tablets, emerge as additional tools for learners to access and manage their PLEs. PLE has potential to bear wider ranges of learning than learners may understand. PLE can be accessed from more traditional selfregulated learning, securing ideal location, allocating specific time for studying, and avoiding any distraction, to just-in-time, bite size, just in enough learning with frequent accessing learning networks through desktop and laptop computers and mobile devices.

The results denote that with relevant SRL skills, learners need additional support to build and manage effective PLE. Castaneda and Soto (2010) contend that learners might not be ready to build effective PLEs, particularly without good understating on the concept of PLE, and effective guidance and support. When learners are allowed to build their PLEs, most of them have only a basic understanding and perception of their PLEs, and few of them 
establish more complex relationships between tools, contents, tasks, social interaction, and themselves in an enriching manner. The majority of learners do not possess the self-regulatory skills, competency, and understanding of social learning paradigms. They do however, value the application of the multi-tool platform to support the tasks, save time, simplify complicated tasks, and have fun.

\subsection{Sense of control}

All six aspects of SRL skills and knowledge are critical to the sense of control because PLE focuses on customizable and personalizable learning that affords learners the ability to learn anytime, anywhere, and with any networked technologies. These skilled and strategic processes in PLE include attention, affect, and monitoring of action such as time management, task strategies, and help seeking, all associated with sense of control. For example, learners can evaluate and select preferred note taking gadgets/ tool/apps to support learning as a strategy to share and collaborate with other learners. Accordingly, they have the freedom and flexibility to use preferred Web 2.0 tools rather than the ones assigned by courses, instructors, or institutions. Worth noting is that learners have lower SRL skills and knowledge in task strategies, time management, help seeking, and self-evaluation while having stronger SRL skills in goal setting and environmental structuring. The learners need support to strengthen their skills in task strategies, time management, help seeking, and self-evaluation for digital PLEs.

\subsection{Level of self-reflection}

All six aspects of SRL skills and knowledge are vital to the level of selfreflection because the internalization acts in
SRL are the ultimate goals for any learning. PLE building is a cycle of externalization and internalization acts, and is in a constant flux. Learners react and respond to their SRL in PLE by self-evaluating the outcomes of their performance. The learners' self-evaluationis based upon social comparisons and adjusts to the implementation of skills and strategies in the level of initiative and sense of control processes for the forthcoming learning tasks. Clearly, self-evaluation skills and strategies are critical to the self-reflection stage; however, the results reveal that the learners have weak self-evaluation skills and knowledge.

This study has been limited to one online course experience in creating and managing PLE. Almost all participants have indicated they would continue using their PLEs for future learning. Unclear is whether learners actually evaluate and reflect current PLE management experience and apply it to their future learning. Future studies should examine learners' PLE management in long-term studies to understand the impact. In addition, PLE is a potentially promising approach, pedagogically, to not only integrate formal and informal learning by the use of social media while supporting student self-regulated learning (Dabbagh \& Kitsantas, 2012). As suggested by Ivanovaand Chatti (2010), educators should foster the organization of self-directed learning with the open network environments in which learners can select their own learning tools, services for the access to content, and human intelligence inside and outside of educational institutions. PLE goes beyond institutional learning and formal learning. PLE is for formal, nonformal, informal, and life-long learning (Marín Juarros etal., 2014).

\subsection{New digital literacy}

Network learning literacy, a new digital 
literacy, might be critical to competent digital learners. Competent digital leaners should be able to apply relevant SRL skills to build their PLEs and manage their learning networks that include people network, tool network, and resource network. With a competent network learning literacy, online or digital learners can be transformed to network learners. They willbe equipped with the sense, understanding, and practice on social, open, and network aspects of network learning.Clearly, new sets of self-regulated learning skills and strategies are critical to build effective PLEs due to more diversified learning forms, learning platforms, and learning strategies and skills. Educators should prepare network learners to gain new sets of self-regulated learning skills and strategies. Because the learners may not be acquainted with new sets of self-regulated learning skills and strategies they mayfeel less of a sense of control over their network learning. Learning is always perceived as formal learning. PLE can be integrated to support formal, non-formal, and informal learning. In fact, a central PLE is able to support formal, non-formal, and informal, and personal learning in a central location to reach lifelong learning goals.

\section{Conclusions}

This study has concluded that all six aspects of SRL could predict PLE management. The results signals the need for pedagogies in designing effective online learning to prepare learners in obtaining authentic meanings of applying network PLE building and management to improve. In addition, it can advance their PLE skills and knowledge by scaffolding their network SRL skills.

Although the learners lend themselves to their SRL approaches in PLE management, this study reveals that learners are inexperienced. Mayor (2004) argue simply providing Web 2.0 tools in the absence of effective PLE building and task scaffolding is inappropriate. Critical is for educators to prepare all learners to advance their SRL to achieve sufficient PLE skills and knowledge to become lifelong digital citizens and learners. Therefore, the implications of PLE go beyond formal learning and extend to non-formal learning and informal learning to become lifelong learners.

Learning is always personal, constructive, ubiquitous, collaborative, and connective. There are imperative needs for pedagogies and research in designing effective network learning in which learners can personalize learning tasks and environments through various self-regulated learning skills and strategies. While network learners are free to organize their own set of network tools, people, and resources, many of them may feel overwhelmed by the complexity of networks, particularly the network tools (Fini, 2009). PLE can be personalized, but this must be networked, connective, and collaborative. Furthermore, while PLE is powered by technology, design and applications should firmly be rooted in the theoretical framework of pedagogy. 


\section{References}

Bandura, A. (1986). Social foundations of thought and action: A social cognitive theory. Englewood Cliffs, NJ: PrenticeHall.

Barnard-Brak, L., Lan, W. Y., \& Paton, V. O. (2010). Profiles in self-regulated learning in the online learning environment. The International Review of Research in Open and Distance Learning, 11(1). Retrieved from http://www.irrodl.org/index.php/ irrodl/article/view/769/1480

Bidarra, J., \&Araújo, J. (2013). Personal learning environments (PLEs) in a distance learning course on mathematics applied to business. European Journal of Open, Distance and E-Learning, 16(1), 141-152.

Buchem, I. (2012). Psychological ownership and PLEs: Do possession and control really matter? Presented at the PLE Conference 2012, Aveiro, Portugal.

Buchem, I., Attwell, G., \& Torres, R. (2011). Understanding personal learning environments: Literature review and synthesis through the Activity Theory lens. In Proceedings of the The PLE Conference 2011 (pp. 1-33). Southampton, UK.: The PLE Conference.

Camacho, M., \&Guilana, S. (2011). From personal to social: Learning environments that work. Digital Education Review, (20), 24-36.

Casquero, O., Ovelar, R., Romo, J., Benito, M., \&Alberdi, M. (2016). Students' Personal Networks in Virtual and Personal Learning Environments: A Case Study in Higher Education Using Learning Analytics Approach. Interactive Learning Environments, 24(1), 49-67.

Casquero, O., Portillo, J., Ovelar, R., Benito, M., \&Romo, J. (2010). iPLE network: An integrated eLearning 2.0 architecture from a university's perspective. Interactive Learning Environments, 18(3), 293-308.

Castaneda, L., \& Soto, J. (2010). Building personal learning environments by using and mixing ICT tools in a professional way. Digital Education Review, (18), 9-25.

Cohen, J., Cohen, P., West, S. G., \& Aiken, L. S. (2003). Applied multiple regression/ correlation analysis for the behavioral sciences (3rd ed.). Mahwah, NJ: Lawrence Erlbaum.

Conole, G. (2008). New schemas for mapping pedagogies and technologies. Ariadne, (56). Retrieved from http://www.ariadne. ac.uk/issue 56/conole/

Dabbagh, N., \&Kitsantas, A. (2012). Personal learning environments, social media, and self-regulated learning: A natural formula for connecting formal and informal learning. The Internet and Higher Education, 15(1), 3-8.

Dabbagh, N., \& Reo, R. (2011). Back to the future: Tracing the roots and learning affordances of social software. In D. W. Surry, T. Stefurak, \& R. Gray (Eds.), Technology integration in higher education: Social and organizational aspects (pp. 1-20). Hershey, PA: IGI Global.

Dede, C. (2008). Theoretical perspectives influencing the use of information technology in teaching and learning. In J. Voogt and G. Knezek, (Eds.), International Handbook of Information Technology in Primary and Secondary Education. New York: Springer.

del Barrio-García, S., Arquero, J. L., \& Romero-Frías, E. (2015). Personal Learning Environments Acceptance Model: The Role of Need for Cognition, e-Learning Satisfaction and Students' Perceptions. Educational Technology \& Society, 18(3), 129-141.

Delen, E., \&Liew, J. (2016). The Use of 
Interactive Environments to Promote Self-Regulation in Online Learning: A Literature Review. European Journal of Contemporary Education, 15(1), 24-33.

Fini, A. (2009). The technological dimension of a massive open online course: The case of the CCK08 course tools. International Review of Research in Open and Distance Learning, 10(5). Retrieved from http:// www.irrodl.org/index.php/irrodl/article/ view/643/1402

Hall, M. (2009). Towards a fusion of formal and informal learning environments: the impact of the read/write web. Electronic Journal of E-Learning, 7(1), 29-40.

Haworth, R. (2016). Personal Learning Environments: A Solution for SelfDirected Learners. TechTrends: Linking Research and Practice to Improve Learning, 60(4), 359-364.

Ivanova, M., \&Chatti, M. A. (2010). Toward a model for the conceptual understanding of personal learning environments: A case study. Journal of Educational Technology Systems, 39(4), 419-439.

Kitsantas, A., \&Dabbagh, N. (2010). Learning to learn with Integrative Learning Technologies (ILT): A practical guide for academic success. Greenwich, CT: Information Age Publishing.

Kožuh, I., Jeremic, Z., Sarjaš, A., Bele, J. L., Devedžic, V., \&Debevc, M. (2015). Social Presence and Interaction in Learning Environments: The Effect on Student Success. Educational Technology \& Society, 18(1), 223-236.

Lai, C.-L., \& Hwang, G.-J. (2016). A selfregulated flipped classroom approach to improving students' learning performance in a mathematics course. Computers \& Education, 100(C), 126-140. http://doi. org/10.1016/j.compedu.2016.05.006

Lee, L. (2016). Autonomous learning through task-based instruction in fully online language courses. Language Learning \&
Technology, 20(2), 81-97.

Lin, J.-W., Lai, Y.-C., Lai, Y.-C., \&Chang, L.-C. (2016). Fostering self-regulated learning in a blended environment using group awareness and peer assistance as external scaffolds. Journal of Computer Assisted Learning, 32(1), 77-93.

MarínJuarros, V., Salinas Ibáñez, J., \& de BenitoCrosetti, B. (2014). Research results of two personal learning environments experiments in a higher education institution. Interactive Learning Environments, 22(2), 205-220.

Martin, J. (2004). Self-regulated learning, social cognitive theory, and agency. Educational Psychologist, 39(3), 135-145.

Mayer, R. E. (2004). Should there be a three-strikes rule against pure discovery learning? The case for guided methods of instruction. American Psychologist, 59(1), 14-19.

Mostmans, L., Vleugels, C., \&Bannier, S. (2012). Raise your hands or handson? The role of computer-supported collaborative learning in stimulating intercreativity in education. Educational Technology \& Society, 15(4), 104-113.

Mott, J. (2010). Envisioning the postLMS era: The open learning network. EDUCAUSE Quarterly, 33(1). Retrieved from http://www.educause.edu/ero/article/ envisioning-post-lms-era-open-learningnetwork

Norusis, M. J. (2012). IBM SPSS statistics 19 statistical procedures companion. Upper Saddle River, NJ: Prentice Hall.

Peters, K. (2007). m-Learning: Positioning educators for a mobile, connected future. International Review of Research in Open and Distance Learning, 8(2), 1-17.

Sahin, S., \&Uluyol, Ç. (2016). Preservice teachers' perception and use of personal learning environments (PLEs). International Review of Research in Open and Distributed Learning, 17(2), 141-161. 
Saz, A., Engel, A., \&Coll, C. (2016). Introducing a personal learning environment in higher education. An Analysis of Connectivity. Digital Education Review, 29, 1-14.

Schunk, D. H. (2001). Social cognitive theory and self-regulated learning. In B. J. Zimmerman \& D. H. Schunk (Eds), Self-regulated learning and academic achievement (2nd ed.). Mahwah, NJ: Lawrence Erlbaum.

Schunk, D. H. (2005). Self-regulated learning: The educational legacy of Paul R. Pintrich. Educational Psychologist, 40(2), 85-94.

Siemens, G. (2007). PLEs - I acronym, therefore I exist. Retrieved July 9, 2009, from http://www.elearnspace. org/blog/2007/04/15/ples-i-acronymtherefore-i-exist/

Siemens, G., \&Matheos, K. (2010). Systemic changes in higher education. Technology \& Social Media, 16(1). Retrieved from http://ineducation.ca/article/systemicchanges-higher-education

Suess, J., \&Morooney, K. (2009). Identity management and trust services: Foundations for cloud computing. EDUCAUSE Review, 44(5), 24-26, 28, $32,34,38,40,42$.

Taraghi, B. (2012). Ubiquitous personal learning environment (UPLE). International Journal of Emerging Technologies in Learning, 7, 7-14.

Turker, M. A., \&Zingel, S. (2008). Formative interfaces for scaffolding self-regulated learning in PLEs, 9. Retrieved from http:// www.elearningeuropa.info/files/media/ media15975.pdf

Valtonen, T., Hacklin, S., Dillon, P., Vesisenaho, M., Kukkonen, J., \&Hietanen, A. (2012). Perspectives on personal learning environments held by vocational students. Computers \& Education, 58(2), 732-739.

vanHarmelen, M. (2006). Personal learning environments. Retrieved March 1, 2009, from http://octette.cs.man.ac.uk/ mark/ docs/MvH_PLEs_ICALT.pdf

vanHarmelen, M. (2008). Design trajectories: Four experiments in PLE implementation. Interactive Learning Environments, 16(1), 35-46.

Vázquez-Cano, E., Martín-Monje, E., LarretaAzelain, C. de, \& Dolores, M. (2016). Analysis of PLEs' implementation under OER design as a productive teachinglearning strategy in higher education. A Case Study at Universidad Nacional de Educación a Distancia. Digital Education Review, (29), 62-85.

Weller, M. (2007, June 12). The Ed Techie: My personal work/leisure/learning environment. Retrieved from http:// nogoodreason.typepad.co.uk/no_good reason/2007/12/my-personal-wor.html

Woolfolk, A. E., Winne, P. H., \& Perry, N. E. (2000). Educational psychology. Scaborough, Ontario, Canada: Allyn and Bacon.

Zimmerman, B. J. (1994). Dimensions of academic self-regulation: A conceptual framework for education. In D. H. Schunk\& B. J. Zimmerman (Eds.), Selfregulation of learning and performance (pp. 3-21). Hillsdale, NJ: Lawrence Erlbaum.

Zimmerman, B. J. (1998). Academic studying and the development of personal skill: A self-regulatory perspective. Educational Psychologist, 33, 73-86.

.2011 .12 .012

\section{Contact the Author}

\section{Cherng-Jyh Yen}

Old Dominion University

Department of Ed. Foundations and Leadership, Old Dominion University, USA

E-mail: cyen@odu.edu 


\section{Chih-Hsiung Tu}

Educational Technology, College of Education,

Northern Arizona University, USA

Email: chih.tu@nau.edu

\section{Laura Sujo-Montes}

Educational Technology, College of Education,

Northern Arizona University, USA

Email: Laura.Sujo-Montes@nau.edu

\section{Karen Sealander}

Special Education, College of Education,

Northern Arizona University, USA

Email: Karen.Sealander@nau.edu

\section{Appendix: Integrated Web 2.0 gadgets/tools on iGoogle/Symbaloo/mobile devices to support PLE}

\begin{tabular}{ll}
\hline Functions & Gadgets/Tools/Apps(or students' choices) \\
\hline Management Tools & \\
$\begin{array}{l}\text { Customized Personal Portal } \\
\text { Learning Resources }\end{array}$ & $\begin{array}{l}\text { Symbaloo, Netvibes, Google Chrome app, Mobile app } \\
\text { Research/Bibliography }\end{array}$ \\
Communication Tools & Zotero, Mendeley \\
Announcements & Twitter \\
Discussion Boards & Wiki discussion forum; Twitter; VoiceThread; Diigo; Nabble; \\
E-mail & multi-dimensional discussions (multiple tools) \\
Web conferencing & Gmail \\
Mobile learning & Skype,Facebook Messenger, LINE, What's App \\
Course content/ & Gmail, Delicious, Diigo, Twitter, Skype, RSS, Facebook, \\
Instruction tools & Google Calendar, Symbaloo, Netvibes \\
Course Content & \\
Calendar & Google Sites \\
Schedule & Google Calendar \\
Assignment Drop Box & Doodle \\
Blogs & Google Docs \\
\hline
\end{tabular}




\section{Production tools}

Documents

Presentations

Mind-Mapping

Collaborative tools

Group Collaboration

Distributed Resource

Tools

Bookmarks

Annotations

Multimedia

Bibliographical

Social Networking Tools

Social Networking

Information Visualization

Tools

Tag/Word Clouds

Timeline-based tool
Google Docs

Google Spreadsheet; Prezi

Webspiration, Mindomo, Gliffy

Wiki, Google Docs

Diigo, Delicious

Diigo

YouTube, Kaizena

Zotero, Mendeley

Facebook, Twitter

Wordle

Dipity, Capzles, HSTRY 